National Water Quality Program

National Water-Quality Assessment Project

\title{
Groundwater Quality in the Edwards-Trinity Aquifer System
}

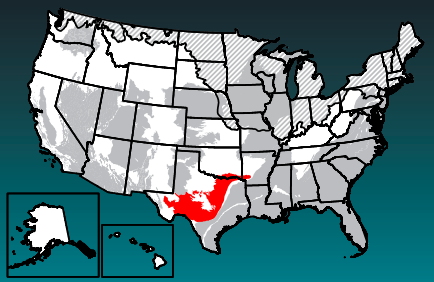

Groundwater provides nearly 50 percent of the Nation's drinking water. To help protect this vital resource, the U.S. Geological Survey (USGS) National WaterQuality Assessment (NAWQA) Project assesses groundwater quality in aquifers that are important sources of drinking water. The Edwards-Trinity aquifer system constitutes one of the important aquifers being evaluated.

\section{Background}

The Edwards-Trinity aquifer system is an important water source with primary water uses for public supply and irrigation. It underlies an area of more than 78,000 square miles $\left(\mathrm{mi}^{2}\right)$, from west Texas to parts of Oklahoma and Arkansas, which is populated by about 11.5 million people. The aquife system ranks 11th in the Nation as a source of groundwater for public supply, with about 411 million gallons per day pumped for this use in 2000; it is also used for agriculture, ranking 22nd for this use with about 282 million gallons per day pumped (Maupin and Barber, 2005; Kingsbury and others, 2021). Land use overlying the aquifer system is composed primarily of natural land cover (including rangeland; 81 percent) and agricultural land (12 percent) with relatively small areas of urban and other developed land (7 percent; Homer and others, 2015). Major urban areas are San Antonio, Austin, Dallas, and Fort Worth, Texas.

The Edwards-Trinity aquifer system is composed of three complexly interrelated aquifers of Cretaceous age carbonate and clastic rocks, which are described in detail by Ryder (1996) and George and others (2011) and summarized herein: from west to east, the aquifers and their respective areas are the Edwards-Trinity aquifer $\left(35,425 \mathrm{mi}^{2}\right)$, the Edwards aquifer $\left(4,052 \mathrm{mi}^{2}\right)$, and the Trinity aquifer $\left(38,663 \mathrm{mi}^{2}\right)$. The Edwards aquifer overlies and is in part hydraulically connected to the Trinity aquifer, whereas the Trinity and Edwards-Trinity aquifers are stratigraphically equivalent in part and hydraulically connected in places. The climate of the region is highly variable with average annual precipitation decreasing from east to west by an order of magnitude; average annual temperature increases from north to south.

The Edwards-Trinity aquifer-locally, the Edwards-Trinity (Plateau) aquifer-extends across much of southwestern Texas and is composed of Edwards Group carbonates in the upper part and Trinity Group sands and carbonates in the lower part. The aquifer is primarily used for irrigation and secondarily for public supply; it accounts for about 9 percent of the aquifer system's public supply. The aquifer slopes generally to the south and southeast, and regional groundwater flow is to the southeast. Recharge occurs by direct precipitation on the land surface where the aquifer is unconfined; in the deeper zones, the aquifer is confined.

The Edwards aquifer-locally, the Edwards (Balcones Fault Zone) aquifer - consists of partially dissolved and highly permeable limestone of the Georgetown Formation and the Edwards Group. The aquifer is present in a narrow band coincident with the Balcones Fault Zone, along which the aquifer dips steeply to the south and southeast with unconfined and confined parts (Maclay and Small, 1983). Geographically, the Edwards aquifer covers the smallest area of the three aquifers (about 5 percent) but is the most productive; public supply is its primary use, which accounts for about 66 percent of the aquifer system's public supply. The Edwards aquifer is one of the most productive aquifers in the Nation (Sharp and Banner, 1997) and is the primary water supply for the city of San Antonio. Recharge occurs primarily by streamflow losses as well as by direct infiltration on the outcrop, or by leakage from the underlying Trinity aquifer. Regional groundwater flow is to the east and northeast. Natural discharge occurs through large springs, which provide habitat for several threatened and endangered species (Texas State University, 2020).

The Trinity aquifer extends across much of central and northeastern Texas in an arcuate band into Oklahoma and Arkansas. It consists of interbedded sandstone, sand, limestone, and shale and is composed of several smaller aquifers that are locally named (for example, it is commonly called the Antlers aquifer in Oklahoma). The aquifer's primary use is public supply (it accounts for about 25 percent of the aquifer system's public supply) with increasing importance north of Austin. It is one of the most extensive and highly used groundwater resources in Texas, and large waterlevel declines have occurred in places. The aquifer dips to the south and southeast with both unconfined and confined parts. It is vertically variable and often divided into the upper, middle, and lower Trinity aquifer. Recharge is primarily from infiltration of rainfall and also some losing streams. Natural discharge occurs to a large number of small (less than 10 cubic feet per second) springs.

Groundwater quality in the Edwards-Trinity aquifer system was evaluated by sampling 74 public-supply wells in 2016 and 2017 . Sampling sites were spatially distributed using a 25-cell equal-area grid for each of the 3 aquifers (only 24 samples were collected from the Edwards-Trinity aquifer) The study area was defined as the depth zone used for public supply in the aquifer system. Summary results for the aquifer system are based on aquiferarea weighting (based on areas of $45.3,5.2$, and 49.5 percent for the Edwards-Trinity, Edwards, and Trinity aquifers, respectively). Water-quality data collected from the spatially distributed wells weighted by aquifer area, are representative of water quality in the study area, following the approach described by Belitz and others (2010). This approach allows for the estimation of the percentage of the study area with concentrations that are high, moderate, and low with respect to constituent benchmarks. The accuracy of the estimates depends on the distribution and number of wells, not the size of the area (Belitz and others, 2010). The wells ranged from 25 to 3,214 feet deep (averaging 846 feet deep); wells in the Edwards-Trinity aquifer were generally shallower (average of 425 feet) than those in the Edwards or Edwards-Trinity aquifers (averages of 952 and 1,126 feet, respectively). Wells were typically open to the aquifers across a range of depth intervals. Samples were analyzed for a large number of water-quality constituents derived from natural and human sources.

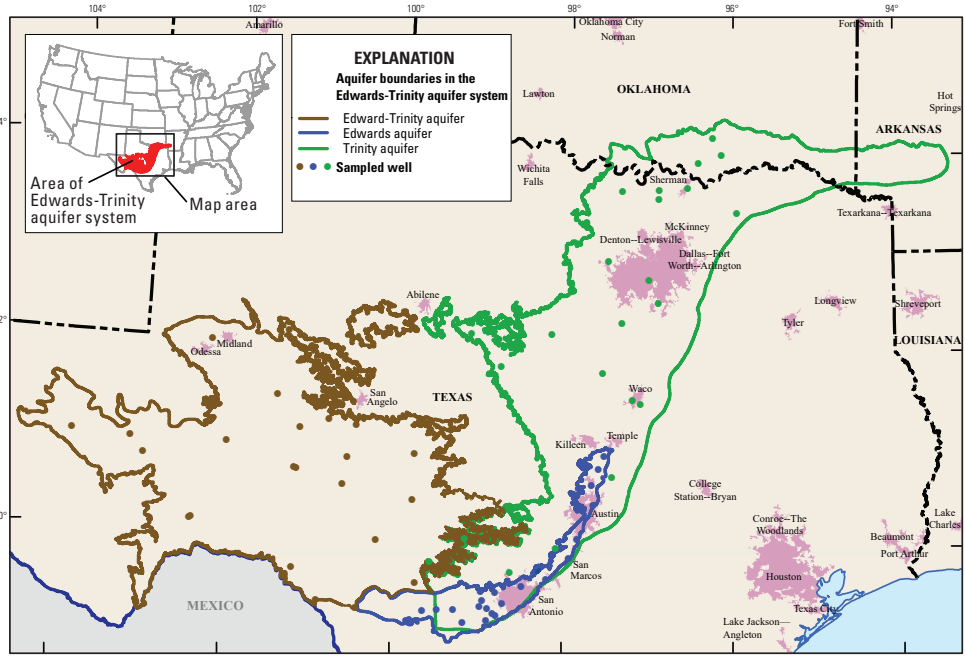

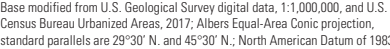

\section{Overview of Water Quality}

Inorganic

Area weighted

Organic

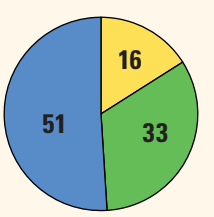

Area weighted

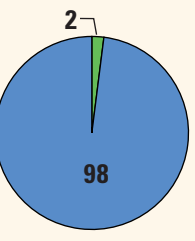

CONSTITUENT CONCENTRATIONS

$\bigcirc$ High $\bigcirc$ Moderate $\bigcirc$ Low or not detect Values are a percentage of the study area with concentrations in the three specified categories. Percentages might rounding.

Principal Aquifer Studies (Burow and Belitz, 2014) are designed to evaluate groundwater used for public supply prior to any treatment. Groundwater quality is assessed by comparing concentrations to benchmarks established for drinking-water quality. Benchmarks and definitions of high, moderate, and low relative concentrations are discussed at the bottom of page 3 . Water from 84 percent of the wells sampled did not have high concentrations of any contaminant measured.

Many inorganic constituents are naturally present in groundwater. The concentrations of inorganic constituents can be affected by natural processes as well as by human activities. One or more inorganic constituents with humanhealth benchmarks were detected at high concentrations in about 16 percent of the area-weighted study area and at moderate concentrations in about 33 percent.

Organic constituents derived from human activities are used in household, business, industrial, and agricultural products. They can enter the environment through normal usage, spills, or improper disposal. Organic constituents with humanhealth benchmarks were detected at moderate concentrations in about 2 percent of the area-weighted study area. 


\section{Results: Groundwater Quality at the Depth Zone Used for Public Supply in the Edwards-Trinity Aquifer System}

\section{INORGANIC CONSTITUENTS}

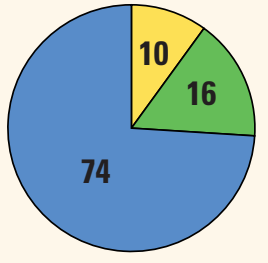

\section{Trace \\ elements and major and minor ions Area weighted}

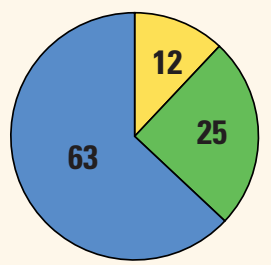

\section{Radioactive constituents Area weighted}
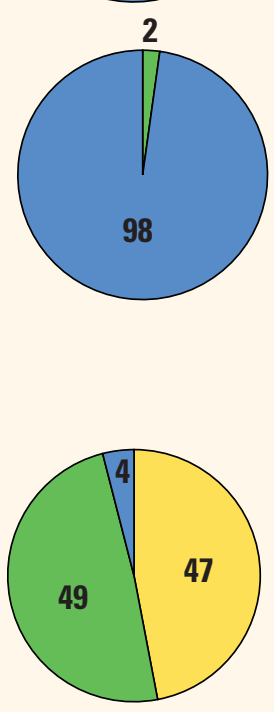

\section{Inorganic Constituents With Human-Health Benchmarks}

Trace elements and major and minor ions are naturally present in the minerals of rocks, soils and sediments, and in the water that comes into contact with those materials. Samples were analyzed for 34 trace elements and major and minor ions, of which 22 have human-health benchmarks (health-based screening level [HBSL] benchmarks were updated in 2018 to include aluminum, cobalt, and iron; Norman and others, 2018). Constituents from this group were detected at high concentrations in about 10 percent of the area-weighted study area (the depth zone used for public supply) and at moderate concentrations in about 16 percent. Strontium was the most commonly detected trace element at both high (10 percent) and moderate (12 percent) concentrations. Molybdenum was detected at moderate concentrations in about 4 percent of the area-weighted study area, and arsenic and thallium were both detected at moderate concentrations in about 2 percent.

Radioactivity is the release of energy or energetic particles during the spontaneous decay of unstable atoms. Humans are continuously exposed to small amounts of natural radioactivity. Most of the radioactivity in groundwater comes from the decay of isotopes of uranium and thorium that are naturally present in minerals in aquifer materials. Samples were analyzed for eight radioactive constituents, of which four have human-health benchmarks. Radioactive constituents were present at high concentrations in about 12 percent of the area-weighted study area, primarily from grossalpha radioactivity. Moderate concentrations occurred in about 25 percent of the area-weighted study area, primarily from gross-alpha radioactivity and combined radium (Ra-226 plus Ra-228).

Nutrients are naturally present at low concentrations in groundwater; high and moderate concentrations (relative to human-health benchmarks) generally result from human activities. Samples were analyzed for five nutrients, of which two (nitrate and nitrite) have human-health benchmarks. Common sources of nutrients, aside from soils, include fertilizer applied to crops and landscaping, seepage from septic systems, and human and animal waste. Nitrate was not measured at high concentrations; it occurred at moderate concentrations in about 2 percent of the areaweighted study area, all in the Edwards-Trinity aquifer.

\section{Inorganic Constituents and Field Measurements With Non-Health-Based Benchmarks}

(Not included in water-quality overview charts shown on the front page)

Some constituents affect the aesthetic properties of water, such as taste, color, and odor, or can create nuisance problems, such as staining and scaling. The benchmarks used for these constituents were non-regulatory secondary maximum contaminant level (SMCL) benchmarks established for public drinking water. Some constituents, such as manganese and fluoride, have human-health benchmarks and SMCLs. Samples were analyzed for 11 constituents that have SMCLs. One or more of these were present at high concentrations relative to the SMCL in about 48 percent of the study area and at moderate concentrations in about 49 percent.

Total dissolved solids (TDS) concentration is a measure of the salinity of the groundwater based primarily on concentrations of ions. All water naturally contains TDS because of the weathering and dissolution of minerals in rocks and sediments. Concentrations of TDS can be high as a result of natural factors or human activities, such as applications to the land surface of road salt, fertilizers, or other chemicals in urban or agricultural areas. Most of the area-weighted study area had high (47 percent) or moderate (49 percent) concentrations of TDS; high concentrations occurred most frequently in the Trinity (68 percent) and Edwards-Trinity ( 29 percent) aquifers. Chloride, fluoride, and sulfate were similarly measured at high concentrations in about 8,8 , and 9 percent of the area-weighted study area, respectively, and at moderate concentrations in about 8 , 33, and 16 percent, respectively.

Anoxic conditions in groundwater (low amounts of dissolved oxygen) can result in the release of iron and manganese in minerals to the groundwater. Iron was occasionally measured at high (6 percent) or moderate ( 2 percent) concentrations in the area-weighted study area, specifically within the Trinity or Edwards-Trinity aquifers; only low concentrations were measured in the Edwards aquifer.

Groundwater $\mathrm{pH}$ has an SMCL range of 6.5 to 8.5. In the Edwards-Trinity aquifer system, $\mathrm{pH}$ was greater than 8.5 , which is alkaline, in about 22 percent of the area-weighted study area, all in the Trinity aquifer. 


\section{Results: Groundwater Quality at the Depth Zone Used for Public Supply in the Edwards-Trinity Aquifer System}

\section{ORGANIC CONSTITUENTS}

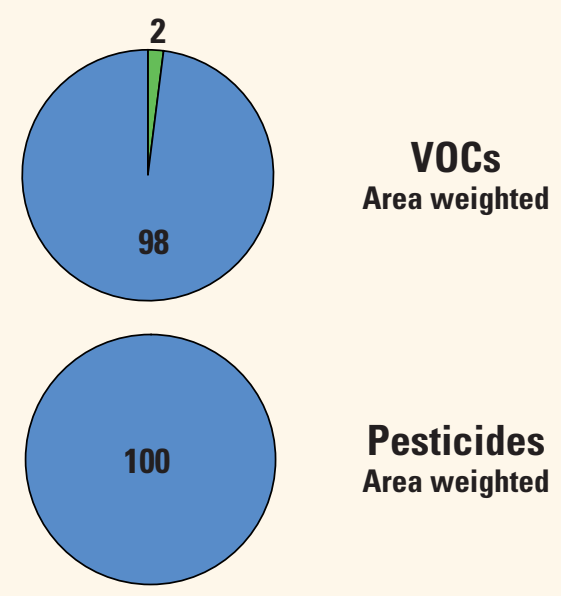

\section{Volatile Organic Compounds With Human-Health Benchmarks}

Volatile organic compounds (VOCs) are present in many household, commercial, industrial, and agricultural products and are characterized by their tendency to volatilize (evaporate). Samples were analyzed for 85 VOCs, of which 51 have human-health benchmarks. VOCs were detected at moderate concentrations in 2 percent of the areaweighted study area (based on tetrachloroethylene-PCE - concentrations in the Trinity aquifer).

\section{Pesticides With Human-Health Benchmarks}

Pesticides, including herbicides, insecticides, and fungicides, are applied to crops, gardens and lawns, around buildings, and along roads to help control unwanted vegetation (weeds), insects, fungi, and other pests. Samples were analyzed for 225 pesticide compounds (pesticides and their breakdown products), of which 119 have human-health benchmarks. Pesticide compounds were not detected at high or moderate concentrations in the study area.

\section{BENCHMARKS FOR EVALUATING GROUNDWATER QUALITY}

The USGS NAWQA Project uses benchmarks established for drinking water to provide context for evaluating the quality of untreated groundwater. The quality of water received by consumers can be different from results presented herein because after withdrawal, groundwater may be treated prior to delivery. Federal regulatory benchmarks for protecting human health are used for this evaluation of water quality when available. Otherwise, non-regulatory human-health benchmarks and nonregulatory aesthetic benchmarks are used. Not all constituents analyzed have benchmarks and, thus, are not considered in this context. There are human-health benchmarks for 28 of 55 inorganic constituents and properties and 170 of 310 organic constituents.

Concentrations are considered high if they are greater than a human-health benchmark (Norman and others, 2018) or SMCL. For inorganic constituents, concentrations are moderate if they are greater than one-half of a benchmark. For organic constituents, concentrations are moderate if they are greater than one-tenth of a benchmark; this lower threshold is used because organic constituents are generally less prevalent and have smaller concentrations relative to benchmarks than inorganic constituents (Toccalino and others, 2004).

\section{Benchmark Type and Value for Selected Constituents}

This table presents benchmarks for those constituents detected at high concentrations in the Edwards-Trinity aquifer system. Benchmark types are regulatory U.S. Environmental Protection Agency (EPA) maximum contaminant levels (MCLs; U.S. Environmental Protection Agency, 2020a), non-regulatory health-based screening levels (HBSLs; Norman and others, 2018) and non-regulatory EPA secondary maximum contaminant levels (SMCLs; U.S. Environmental Protection Agency, 2020b).

$[\mu \mathrm{g} / \mathrm{L}$, microgram per liter; $\mathrm{mg} / \mathrm{L}$, milligram per liter; $\mathrm{pCi} / \mathrm{L}$, picocurie per liter]

\begin{tabular}{|c|c|c|c|c|c|}
\hline \multirow{2}{*}{ Constituent } & \multicolumn{2}{|c|}{ Benchmark } & \multirow{2}{*}{ Constituent } & \multicolumn{2}{|c|}{ Benchmark } \\
\hline & Type & Value & & Type & Value \\
\hline Radium-226 & MCL & $5 \mathrm{pCi} / \mathrm{L}$ & Sulfate & SMCL & $250 \mathrm{mg} / \mathrm{L}$ \\
\hline Radium $226+228$ & MCL & $5 \mathrm{pCi} / \mathrm{L}$ & Chloride & SMCL & $250 \mathrm{mg} / \mathrm{L}$ \\
\hline Gross-alpha activity & MCL & $15 \mathrm{pCi} / \mathrm{L}$ & Fluoride & SMCL & $2 \mathrm{mg} / \mathrm{L}$ \\
\hline Strontium & HBSL & $4,000 \mu \mathrm{g} / \mathrm{L}$ & Iron & SMCL & $300 \mu \mathrm{g} / \mathrm{L}$ \\
\hline $\begin{array}{r}\text { Total dissolved } \\
\text { Solids (TDS) }\end{array}$ & SMCL & $500 \mathrm{mg} / \mathrm{L}$ & $\mathrm{pH}$ & SMCL & $6.5-8.5$ \\
\hline
\end{tabular}

\section{PERCENTAGE OF STUDY AREA}

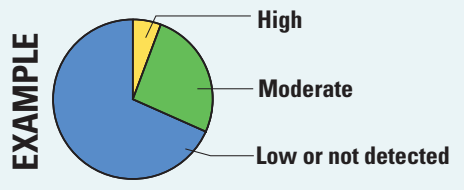

Values are a percentage of the study area with concentrations in the three specified categories. Percentages might not sum to 


\section{Constituents with Moderate and High Concentrations Vary by Aquifer}

Several inorganic constituents with human-health benchmarks or with secondary non-health benchmarks commonly were measured at high and moderate concentrations in the Edwards-Trinity aquifer system using area-weighed proportions. The most prevalent with humanhealth benchmarks were strontium, gross-alpha radioactivity, and combined radium; the most prevalent with secondary non-health benchmarks were TDS, fluoride, and sulfate. The distribution of these constituents, however, varied in the three aquifers. Moderate and high concentrations of constituents with health-based benchmarks were most common in the Edwards-Trinity and Trinity aquifers, occurring in 54 and 48 percent of the study areas, respectively. High concentrations of strontium occurred in all three aquifers similarly (8 to 13 percent), while radioactive constituents were less common in the Edwards aquifer. Relative to SMCLs, moderate and high concentrations of TDS were dominant in all three aquifers, but high concentrations were most common in the Trinity aquifer (68 percent) and did not occur in the Edwards aquifer. High and moderate concentrations of chloride, sulfate, and fluoride each occurred in more than 15 percent of the Edwards-Trinity and Trinity aquifers, whereas only fluoride had elevated concentrations in the Edwards aquifer. Iron also occurred at high or moderate concentrations in the Edwards-Trinity and Trinity aquifers, but not in the Edwards aquifer. These differences in water quality in the three aquifers that make up the aquifer system likely reflect a number of factors, such as differences in the composition of aquifer rocks, flow-path characteristics, geochemical conditions, groundwater age distributions, and climate

\section{By MaryLynn Musgrove}
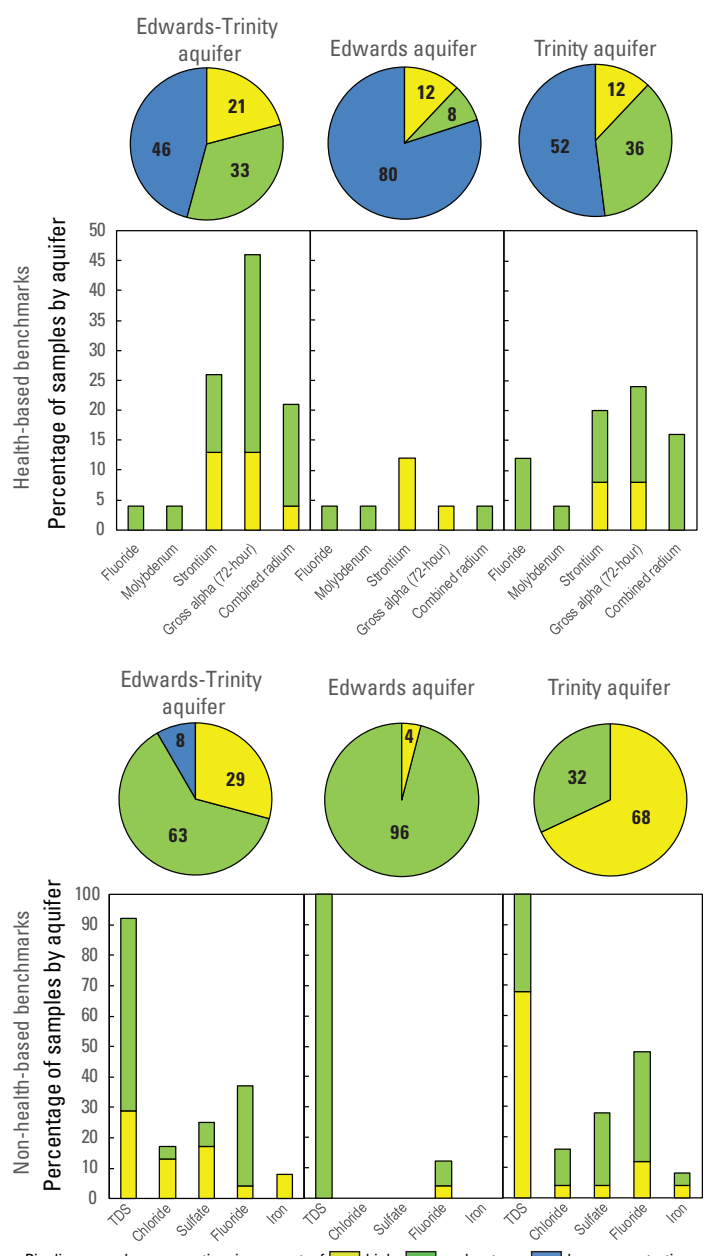

Pie diagrams show proportion, in percent, of $\square$ high, $\square$ moderate, or $\square$ low concentrations for each of the three aquifers in the Edwards-Trinity aquifer system for all inorganic constituents with health-based (top) and non-health-based (bottom) benchmarks. Histograms detail high and moderat proportions in each of the three aquifers for the most commonly occurring of these constituents.

\section{REFERENCES CITED}

Belitz, K., Jurgens, B., Landon, M.K., Fram, M.S., and Johnson, T., 2010, Estimation of aquifer scale proportion using equal area grids-Assessment of regional scale groundwater quality: Water Resources Research., v. 46, 14 p., https://doi.org/10.1029/2010WR009321.

Burow, K.R., and Belitz, K., 2014, Groundwater studies—Principal aquifer surveys: U.S. Geological Survey Fact Sheet 2014-3024, 2 p., https://doi.org/10.3133/fs20143024. Bush, P.W., Ardis, A.F., Fahlquist, L., Ging, P.B., Hornig, C.E., and Lanning-Rush, J., 2000, Water quality in south-central Texas, 1996-1998: U.S. Geological Survey Circular 1212, 32 p., https://doi.org/10.3133/cir1212.

DeSimone, L.A., McMahon, P.B., and Rosen, M.R., 2014, The quality of our Nation's waters-Water quality in principal aquifers of the United States, 1991-2010: U.S. Geological Survey Circular 1360, 151 p., https://doi.org/10.3133/cir1360.

George, P.G., Mace, R.E., and Petrossian, R., 2011, Aquifers of Texas: Texas Water Development Board, Report 380, 172 p., accessed January 5, 2018, at http://www.twdb.texas.gov/publications/reports/numbered_reports/doc/R380_AquifersofTexas.pdf?d=5431.47.

Homer, C.G., Dewitz, J.A., Yang, L., Jin, S., Daniel`son, P., Xian, G., Coulston, J., Herold, N.D., Wickham, J.D., and Megown, K., 2015, Completion of the 2011 National Land Cover Database for the conterminous United States - Representing a decade of land cover change information: Photogrammetric Engineering and Remote Sensing, v. 81 , no. 5, p. 345-354, https://pubs.er.usgs.gov/publication/70146301.

Kingsbury, J.A., Bexfield, L.M., Arnold, T., Musgrove, M., Erickson, M.L., Degnan, J.R., Tesoriero, A.J., Lindsey, B.D., and Belitz, K., 2021, Groundwater-quality and select quality-control data from the National Water-Quality Assessment Project, January 2017 through December 2019: U.S. Geological Survey Data Series 1136,97 p., https://doi.org/10.3133/ds1136.

Kingsbury, J.A., Sharpe, J.B., Bexfield, L.M., Arnold, T.L., Musgrove, M., Erickson, M.L., Degnan, J.R., Tesoriero, A.J., Lindsey, B.D., and Belitz, K., 2020, Datasets of groundwater-quality and select quality-control data from the National Water-Quality Assessment Project, January 2017 through December 2019 (ver. 1.1, January 2021) U.S. Geological Survey data release, https://doi.org/10.5066/P9XATXV1.

Maclay, R.W., and Small, T.A., 1983, Hydrostratigraphic subdivisions and fault barriers of the Edwards aquifer, south-central Texas, U.S.A.: Journal of Hydrology, v. 61, p. $127-146$

Maupin, M.A., and Barber, N.L., 2005, Estimated withdrawals from principal aquifers in the United States, 2000: U.S. Geological Survey Circular 1279,46 p., https://doi.org/10.3133/cir1279.

Musgrove, M., Fahlquist, L., Houston, N.A., Lindgren, R.J., and Ging, P.B., 2010, Geochemical evolution processes and water-quality observations based on results of the National Water-Quality Assessment Program in the San Antonio segment of the Edwards aquifer, 1996-2006: U.S. Geological Survey Scientific Investigations Report 2010-5129, 93 p., https://doi.org/10.3133/sir20105129.

Norman, J.E., Toccalino, P.L., Morman, S.A., 2018, Health-based screening levels for evaluating water-quality data (2d ed.): U.S. Geological Survey National Water-Quality Assessment Program web page, https://doi.org/10.5066/F71C1TWP.

Ryder, P.D., 1996, Ground water atlas of the United States: segment 4, Oklahoma, Texas: U.S. Geological Survey Hydrologic Atlas no. HA-730E, accessed December 12, 2017 at https://doi.org/10.3133/ha730E.

Sharp, J.M., Jr., and Banner, J.L., 1997, The Edwards aqui-fer—A resource in conflict: Geological Society of America (GSA) Today, v. 7, p. 1-9.

Texas State University, 2020, Edwards Aquifer Research and Data Center-Threatened and endangered species in the Edwards aquifer system: Texas State University College of Science and Engineering web page, accessed January 2020 at http://www.eardc.txstate.edu/Aquifer-Info/endangered.html.

Toccalino, P.L., Norman, J.E., Phillips, R.H., Kauffman, L.J., Stackelberg, P.E., Nowell, L.H., Krietzman, S.J., and Post, G.B., 2004, Application of healthbased screening levels to ground-water quality data in a state-scale pilot effort: U.S. Geological Survey Scientific Investigations Report 2004-5174, 64 p., https://doi.org/10.3133/sir20045174.

U.S. Environmental Protection Agency, 2020a, National primary drinking water regulations: U.S. Environmental Protection Agency web page, accessed March 2020 at https://www.epa.gov/ground-water-and-drinking-water/national-primary-drinking-water-regulations.

U.S. Environmental Protection Agency, 2020b, Secondary drinking water standards-Guidance for nuisance chemicals: U.S. Environmental Protection Agency web page, accessed March 2020 at https://www.epa.gov/sdwa/secondary-drinking-water-standards-guidance-nuisance-chemicals.

\section{Principal Aquifer Studies}

The USGS NAWQA Project

has been assessing the quality of groundwater since 1991. The NAWQA studies include Land Use Studies (LUS), Major Aquifer Studies (MAS), and Principal Aquifer Studies (PAS). These three study types are based on sampling networks of wells distributed across an area of interest. The LUS networks typically consist of observation wells that are relatively shallow; MAS networks typically consist of domestic-supply wells that are intermediate in depth; and PAS networks typically consist of public-supply wells that are relatively deep. A national synthesis of shallow and intermediate depth groundwater quality was reported by DeSimone and others (2014). A regional synthesis of water quality for parts of the EdwardsTrinity aquifer system was reported by Bush and others (2000) and Musgrove and others (2010). This fact sheet provides a summary of PAS data for 74 public-supply wells sampled in 2016 and 2017 in the Edwards-Trinity aquifer system (data available in Kingsbury and others, 2020b).

The PAS assessments like this one allow for the comparison of constituent concentrations in untreated groundwater with benchmarks established for the protection of human health and for aesthetic qualities of drinking water and also provide a basis for comparison of groundwater quality among the principal aquifers.

The data collected by the NAWQA Project include chemical analyses generally not available as part of regulatory compliance monitoring, including measurements at concentrations much lower than the levels used as human-health benchmarks and measurement of constituents that can be used to trace the sources and movement of groundwater.

\section{For more information}

Technical reports and hydrologic data collected for the USGS NAWQA Project may be obtained from

\section{Program Coordinator \\ U.S. Geological Survey \\ Water Availability and Use Science Program}

Email: wausp-info@usgs.gov WEB: https://water.usgs.gov/ nawqa

ISSN 2327-6916 (print) ISSN 2327-6932 (online) https://doi.org/10.3133/fs20213010 